\title{
Struktury peryglacjalne na stanowisku Łubienica-Superunki (Wysoczyzna Ciechanowska) - wstępne wyniki badań
}

\author{
Periglacial structures on site Łubienica-Superunki (Ciechanowska Upland) - preliminary results
}

\section{Maciej Dąbski*, Urszula Zawadzka-Pawlewska, Katarzyna Greń}

Uniwersytet Warszawski, Wydział Geografii i Studiów Regionalnych; *mfdbski@uw.edu.pl

\begin{abstract}
Zarys treści: W zachodniej części piaskowni Łubienica-Superunki, położonej na Wysoczyźnie Ciechanowskiej (północne Mazowsze), stwierdzono występowanie struktur peryglacjalnych, takich jak: inwolucje, bruk peryglacjalny oraz pseudomorfozy po dużych epigenetycznych klinach mrozowych z wypełnieniem lodowo-piaszczystym (ang. composite wegdes). Struktury te wykształcone są w większości bezpośrednio pod współczesną glebą i warstwą piasków pokrywowych o małej miąższości poza jednym z klinów, który występuje w obrębie osadów fluwioglacjalnych w transgresji młodszego stadiału zlodowacenia warty.
\end{abstract}

Słowa kluczowe: inwolucje, bruk peryglacjalny, kliny mrozowe, Równina Ciechanowska

Abstract: In the western part of the Łubienica-Superunki sand pit, located on the Ciechanowska Upland (northern Mazovia), periglacial structures were observed such as: involutions, periglacial pavement and large epigenetic composite wegde psuedomorphs. The structures occur usually below contemporary topsoil and thin layer of cover sands, besides one frost wedge, which is developed in fluvioglacial sediments from transgression of younger Saalian ice sheet.

Key words: involutions, periglacial pavement, frost wedges, Ciechanowska Upland

\section{Wstęp}

Celem artykułu jest przedstawienie wstępnych wyników badań struktur peryglacjalnych uwidaczniających się w piaskowni Łubienica-Superunki (ryc. 1) położonej między Serockiem a Pułtuskiem przy wschodniej krawędzi Wysoczyzny Ciechanowskiej. Występowanie tego typu struktur na północnym Mazowszu dotychczas nie zostało dobrze udokumentowane.

Piaskownia jest obiektem bardzo dużym $(1,5 \mathrm{~km}$ na $0,8 \mathrm{~km}$ ), ponadto, ze względu na szybko przebiegającą eksploatację, trudno jest zarejestrować i opisać wszystkie struktury sedymentacyjne mogące być przedmiotem szczególnego zainteresowania ze strony geomorfologa. Badania struktur geologicznych mają tu zatem charakter ratowniczy i niepełny. Ob-

Ryc. 1. Mapa lokalizacyjna badanego stanowiska (źródło: Google Earth)

Fig. 1. Location map of the Łubienica-Superunki sand pit (based on: Google Earth)

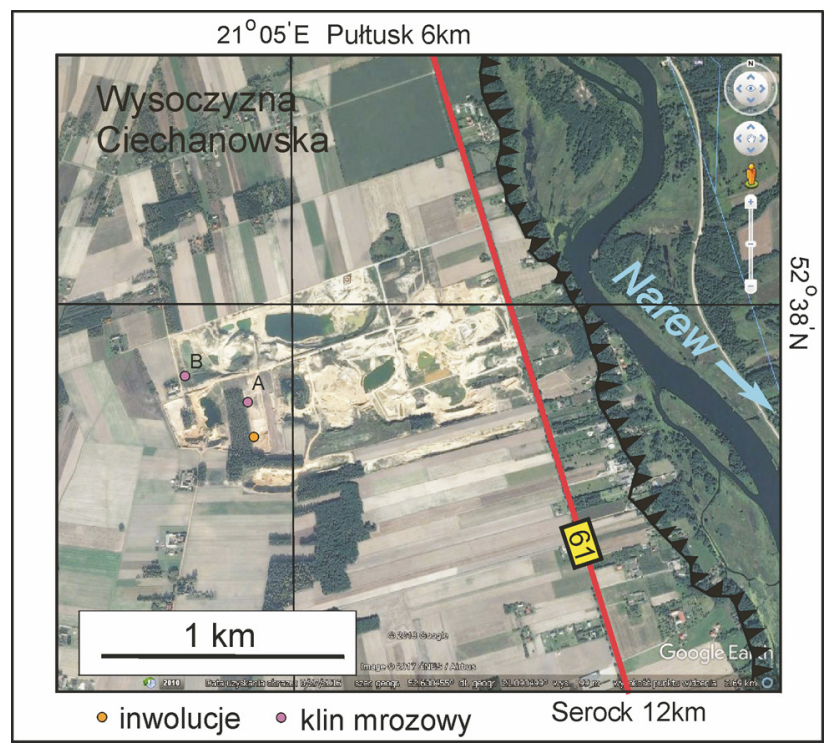


$S$

$$
\text { m n.p.m. }
$$

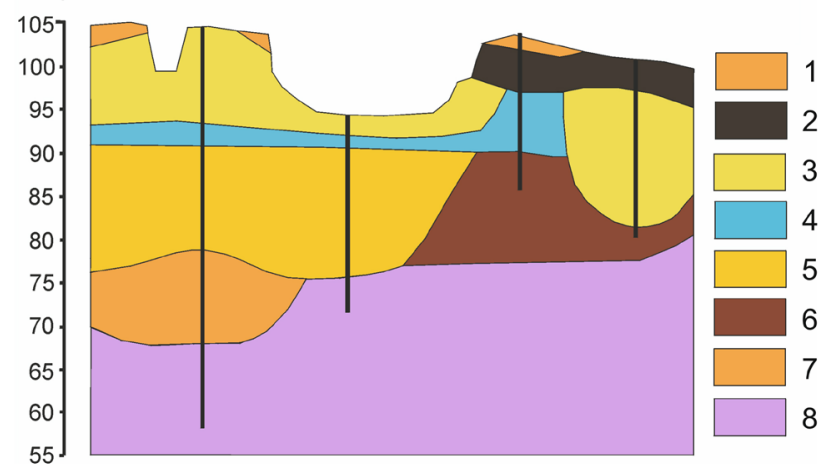

szar ten stanowi obecnie przedmiot badań geologów z Państwowego Instytutu Geologicznego w ramach prac nad reambulacją SMGP, arkusz Serock. Układ osadów czwartorzędowych w miejscu piaskowni przedstawiono na rycinie 2 .

Szczegółowa analiza osadów na miejscu pozwoliła stwierdzić następującą sekwencję osadów w SW części piaskowni, gdzie stwierdzono występowanie struktur mrozowych (ryc. 1). Bezpośrednio pod
Ryc. 2. Przekrój geologiczny (N-S) przez piaskownię Łubienica-Superunki (źródło: Frankiewicz 2017)

1 - eluwia warciańskiej gliny zwałowej, 2 - glina zwałowa młodszego stadiału zlodowacenia warty, 3 - piaski i żwiry wodnolodowcowe $z$ transgresji młodszego stadiału zlodowacenia warty, 4 - iły zastoiskowe, 5 - piaski i żwiry wodnolodowcowe z recesji starszego stadiału zlodowacenia warty, 6 - glina zwałowa starszego stadiału zlodowacenia warty, 7 - piaski i żwiry wodnolodowcowe z recesji zlodowacenia odry, 8 - neogeńskie iły pstre

Fig. 2. Geological cross-section (N-S) through the Eubienica-Supernki sand pit (based on: Frankiewicz 2017)

1 - eluvium of Warthanian glacial till, 2 - glacial till from younger stadial of Warthanian, 3 - fluvioglacial sands and gravels from transgression of younger stadial of Warthanian, 4 - varved clay, 5 - fluvioglacial sands and gravels from recession of older stadial of Warthanian, 6 - glacial till from older stadial of Warthanian, 7 - fluvioglacial sands and gravels from recession of Odranian, 8 - Neogene clays

współczesną glebą zalegają eoliczne piaski pokrywowe laminowane horyzontalnie, które nie zostały ujęte na schematycznym przekroju geologicznym (ryc. 2), prawdopodobnie ze względu na jego niewielką skalę. Kolejnym osadem jest glina zwałowa $z$ młodszego stadiału zlodowacenia warty, pod którą występuje miąższa seria osadów fluwioglacjalnych (ryc. 3).

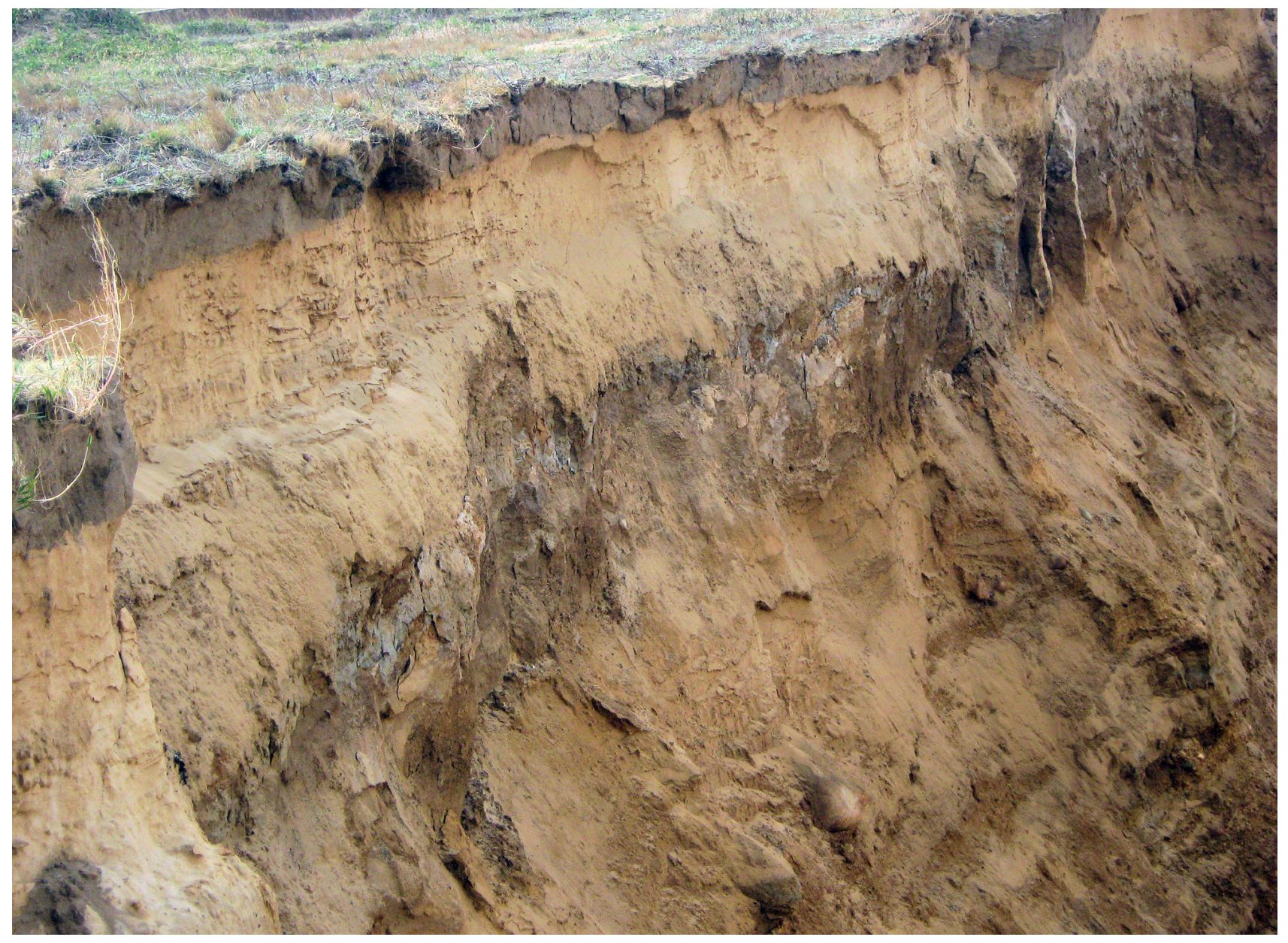

Ryc. 3. Typowa sekwencja osadów (od góry): współczesny poziom próchniczny, piaski pokrywowe, glina lodowcowa, piaski i żwiry fluwioglacjalne

Fig. 3. Typical sedimentary sequence (from top): contemporary topsoil, cover sands, glacial till, fluvioglacial sand and gravel 


\section{Metody badań}

W terenie zidentyfikowano utwory geologiczne tworzące struktury peryglacjalne, wykonano dokumentację fotograficzną, analizę ułożenia głazików w warstwie bruku oraz analizę obecności węglanów (reakcja z $\mathrm{HCl}$ ). Analizy laboratoryjne obejmowały określenie składu mechanicznego metodą kombinowaną oraz obtoczenia i zmatowienia ziaren kwarcu (Mycielska-Dowgiałło, Woronko 1998). Wyniki analizy składu mechanicznego zestawiono z krzywą określającą limit wysadzinowości Beskowa (1935) w celu określenia podatności na pęcznienie mrozowe. Zdjęcia inwolucji zestawiono w jeden ciąg przedstawiający całą szerokość stanowiska oraz wykonano ich rysunkową interpretację.

\section{Wyniki badań i interpretacja}

W ścianach piaskowni widocznych jest niewiele struktur mrozowych typowych dla wieloletniej zmarzliny lub dla warstwy czynnej. Jedynie w trzech miejscach udało się je zaobserwować (ryc. 1); są to inwolucje i bruk peryglacjalny (ryc. 4) i dwie struktury dużych klinów mrozowych (ryc. 5, 7).

\section{Inwolucje i bruk peryglacjalny}

Na głębokości około 0,5 m pod współczesnym poziomem próchnicznym w SW części piaskowni zaobserwowano wyraźny poziom głazików, który autorzy interpretują jako zapis pęcznienia mrozowego prowadzącego do podnoszenia mrozowego grubej

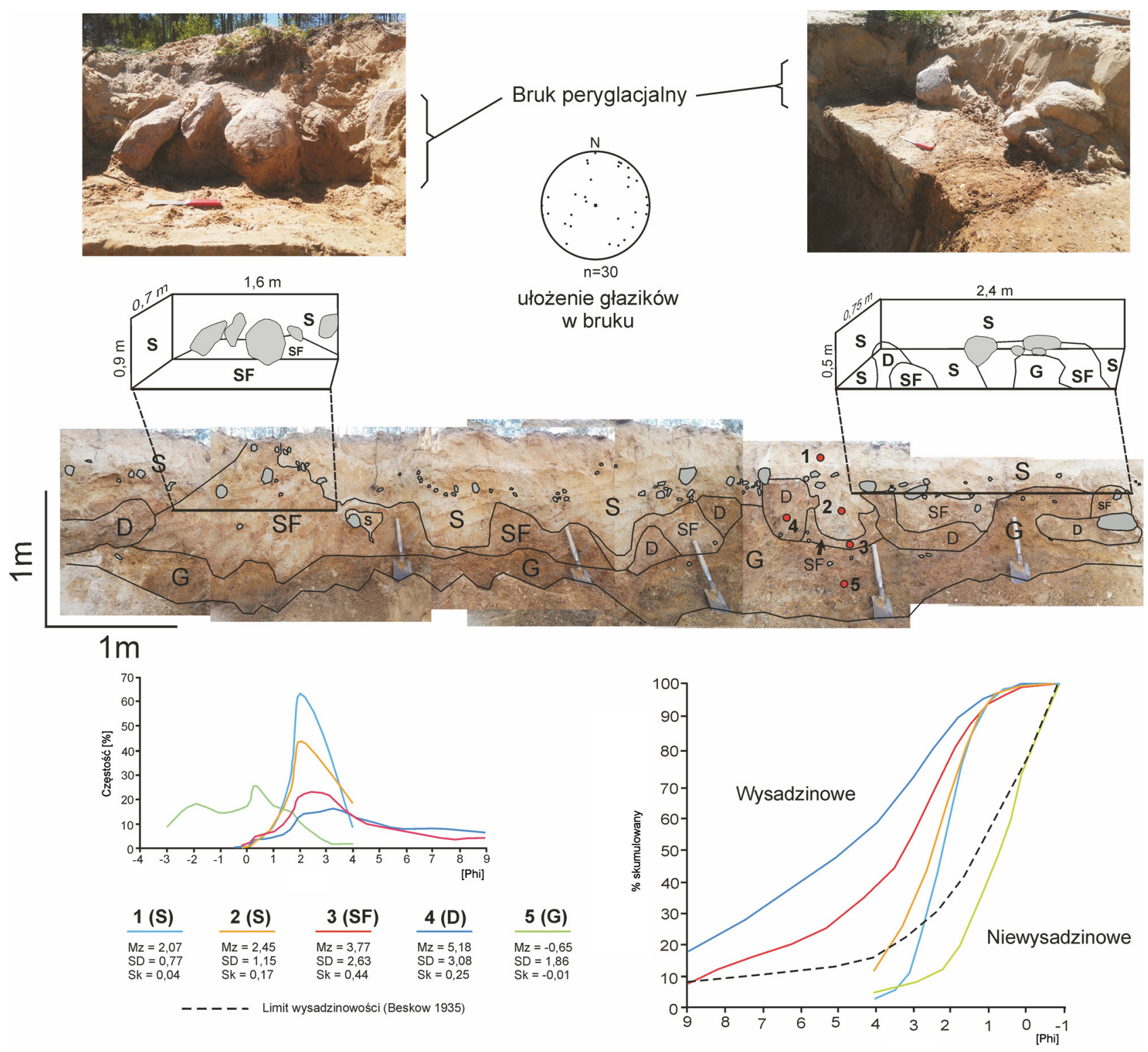

Ryc. 4. Cechy strukturalne i teksturalne osadów tworzących inwolucje i bruku peryglacjalnego

Fig. 4. Structural and textural features of involutions and periglacial pavement 
frakcji (van Everdingen 1998), a pod nim inwolucje typowe dla warstwy czynnej wieloletniej zmarzliny. W analizowanym przekroju stwierdzono następującą sekwencję osadów poniżej współczesnego poziomu próchnicznego (ryc. 4):

- piaski pokrywowe (S) o niewyraźnej horyzontalnej laminacji i średnim wysortowaniu (próbka 1) zalegające do głębokości około 0,3 m (wszystkie głębokości określono względem spągu współczesnego poziomu próchnicznego),

- poziom bruku na głębokości 0,3-0,5 m,

- piaski o zatartym warstwowaniu (S) występujące bezpośrednio pod poziomem bruku, charakteryzujące się wysortowaniem słabym na granicy ze średnim (próbka 2),

- piaski gliniaste (SF) o bardzo słabym wysortowaniu (próbka 3),

- glina lodowcowa (D), próbka 4,

- żwiry wodnolodowcowe słabo wysortowane $(G)$, próbka 5.

Piaski gliniaste i glina lodowcowa są osadami wysadzinowymi, czyli są podatne na tworzenie się lodu segregacyjnego a co za tym idzie - na pęcznienie mrozowe (Beskow 1935). Badane osady są odwapnione, jedynie glina lodowcowa wykazuje miejscami obecność węglanu wapnia (burzy z kwasem solnym).

Strop żwirów fluwioglacjalnych wykazuje znaczne zaburzenia o amplitudzie do 0,5 m. Zalegająca bezpośrednio powyżej warstwa gliny zwałowej (D) jest nieciągła i wykształcona $\mathrm{w}$ formie soczewek o grubości 0,2-0,5 m i długości 0,3-1,0 m, które bezpośrednio kontaktują się z piaskiem (S) lub oddzielo-

Tabela 1. Obtoczenie i zmatowienie ziaren kwarcowych w piaskach pokrywowych (próbka 1)

Table 1. Frosting and rounding of quartz grains from cover sand (sample 1)

\begin{tabular}{lcc}
\hline \multirow{2}{*}{ Próbka/Sample 1 } & $\begin{array}{c}\text { frakcja/fraction } \\
1-0,8 \mathrm{~mm}\end{array}$ & $\begin{array}{c}\text { frakcja/fraction } \\
0,8-0,5 \mathrm{~mm}\end{array}$ \\
\cline { 2 - 3 } & \multicolumn{2}{c}{$[\%]$} \\
\hline NU & 0,0 & 0,9 \\
RM & 18,0 & 12,5 \\
EL & 0,0 & 0,0 \\
EM/RM & 59,0 & 68,5 \\
EM/EL & 8,0 & 3,6 \\
C & 11,0 & 7,1 \\
Inne/other & 4,0 & 1,8 \\
Kwarc/quartz & 82,0 & 88,0 \\
\hline
\end{tabular}

NU - świeże, obtoczenie 0,1-0,2; RM - matowe okrągłe; obtoczenie 0,7-0,9; EL - błyszczące zaokrąglone; obtoczenie 0,7-0,9; EM/RM - matowe pośrednie; obtoczenie 0,3-0,6; EM/ EL - błyszczące pośrednie; obtoczenie 0,3-0,6; C - pęknięte (Krumbein 1941, Mycielska-Dowgiałło, Woronko 1998).

NU - fresh, rounding 0,1-0,2; RM - rounded mat; rounding 0,7-0,9; EL - shiny rounded; rounding 0,7-0,9; EM/RM - partly rounded mat; rounding $0,3-0,6$; EM/EL - partly rounded shiny; rounding 0,3-0,6; C - crushed (Krumbein 1941, Mycielska-Dowgiałło, Woronko 1998). ne są od niego soczewkami piasku gliniastego (SF). Z lewej strony przekroju (część S) uwidacznia się wyciśnięcie piasków gliniastych aż do współczesnego poziomu próchnicznego. Po prawej stronie (część N) obserwuje się gwałtowne podniesienie stropu żwirów fluwioglacjalnych (G), które w części stanowią pokrywę soczewki gliny lodowcowej. Bruk peryglacjalny charakteryzuje się występowaniem znacznej liczby głazów ustawionych płaszczyzną największego przekroju pod dużym kątem w stosunku do poziomu (od 5 do $25 \mathrm{~cm}$ najdłuższa oś) oraz falistym, nierównym przebiegiem.

Przeprowadzono pilotażową analizę obtoczenia i zmatowienia ziaren kwarcu w piasku pokrywowym (próbka 1, ryc. 4, tab. 1).

Wyniki tej analizy wskazują na znaczą eolizację materiału w piaskach pokrywowych, jednakże ze względu na spory udział ziarn niekwarcowych (8\%) oraz zdecydowanie największy udział ziaren typu EM/RM wnioskuje się, że transport eoliczny nie był długi (Barczuk, Mycielska-Dowgiałło 2001, Woronko 2012). W poziomie bruku peryglacjalnego nie stwierdzono obecności eologliptolitów.

\section{Kliny mrozowe}

W odległości około $200 \mathrm{~m}$ na $\mathrm{N}$ od opisanych inwolucji zlokalizowano strukturę dużego klina mrozowego wykształconego w piaskach i żwirach wodnolodowcowych $z$ transgresji lądolodu (ryc. 2). Widoczna struktura klina występuje bezpośrednio pod osadami koluwialno-deluwialnymi związanymi $z$ funkcjonowaniem drogi, którą ciężarówki zjeżdżają na najniższy poziom piaskowni (brązowa horyzontalna warstwa bezpośrednio nad strukturą mrozową, ryc. 5), kilkanaście metrów poniżej inwolucji. Powyżej drogi nie stwierdzono kontynuacji klina. Lejkowate rozszerzenie górnej części klina i brak charakterystycznego kształtu „pnia palmy” (zapis etapowego podwyższania stropu wieloletniej zmarzliny) w środkowej części sugeruje, że jest to klin epigenetyczny. Szerokość piaszczystego wypełnienia klina $\mathrm{w}$ jego górnej części wynosi około $0,5 \mathrm{~m}$, natomiast wyraźne ugięcie warstw piasków i żwirów wodnolodowcowych ku dołowi klina obserwowane jest na prawie $2 \mathrm{~m}$ po obu jego stronach. Głębokość klina przekracza $4 \mathrm{~m}$. Takie ułożenie warstw osadów pozwala wnioskować, że jest to pseudomorfoza po klinie lodowym, jednakże uziarnienie piasku stanowiącego środek wypełnienia tej struktury (ryc. 6) sugeruje, że był to klin złożony (ang. composite wedge), z pierwotnym wypełnieniem lodowo-piaszczystym. Tak duży klin mrozowy i jego umiejscowienie wskazuje na długie funkcjonowanie wieloletniej zmarzliny na przedpolu transgredującego lądolodu młodszego stadiału warty oraz długą przerwę $\mathrm{w}$ akumulacji osadów fluwioglacjalnych w tym miejscu. 


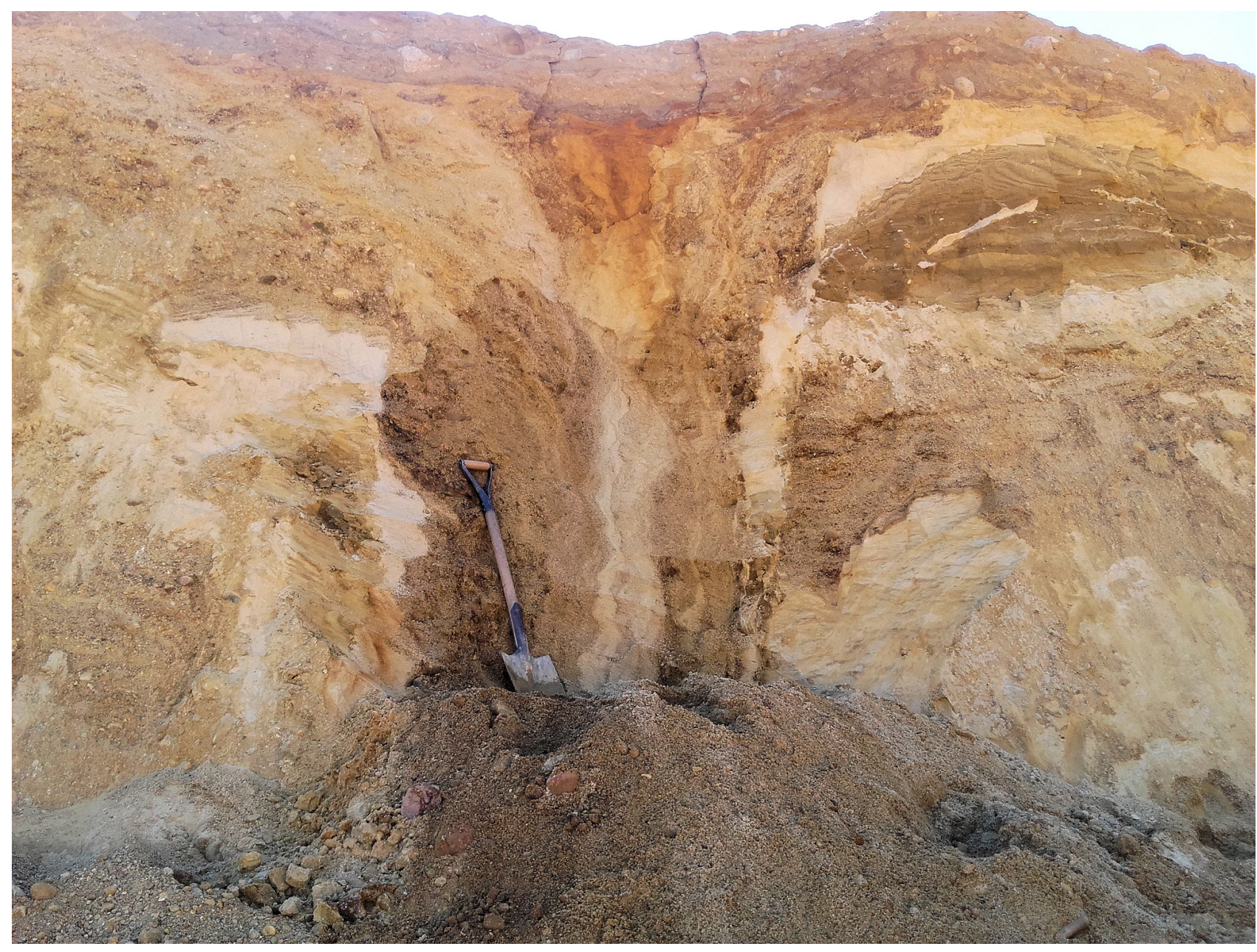

Ryc. 5. Klin mrozowy A: pseudomorfoza po klinie lodowym wypełniona piaskiem eolicznym w środkowej części; w górnej części struktura klina jest ścięta powierzchnią drogi, na której osadziły się współczesne osady koluwialno-deluwialne

Fig. 5. Frost wedge A: ice wedge pseudomorph filled with aeolian sands in its inner part; upper part of the wedge is replaced by the road on which contemporary colluvium was

Piasek wypełniający środkową część klina mrozowego A charakteryzuje się stosunkowo dobrym wysortowaniem i wyraźnym jednomodalnym, symetrycznym rozkładem częstości (ryc. 6). W osadzie

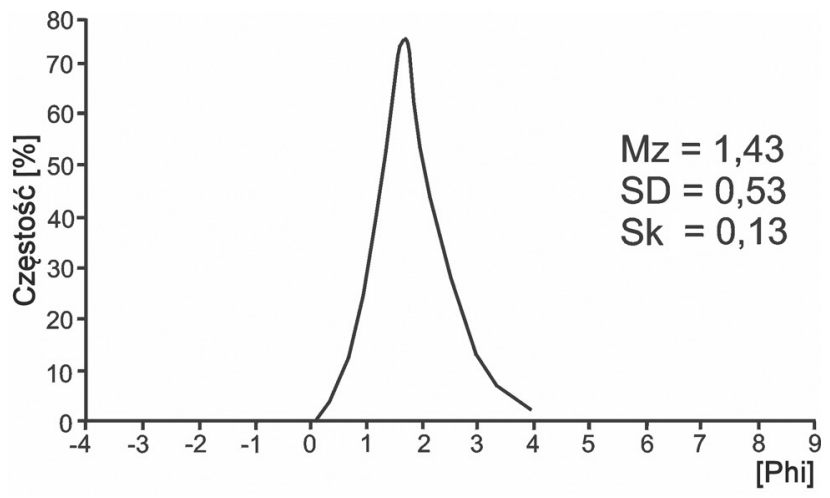

Ryc. 6. Uziarnienie piaszczystego wypełnienia środka klina mrozowego A

Fig. 6. Grain size distribution of the middle part of frost wedge A infill tym jest stosunkowo niedużo ziarn RM i EM/EL (tab. 2), jednak ziarna niekwarcowe wykazują dobre

Tabela 2. Obtoczenia i zmatowienia ziaren kwarcowych ze środka piaszczystego wypełnienia klina mrozowego A (próbka K); objaśnienia skrótów jak przy tabeli 1

Table 2. Frosting and rounding of quartz grains from middle of frost wedge infill (sample K); explanations of acronyms as for Table 1

\begin{tabular}{lcc}
\hline \multirow{2}{*}{ Próbka/Sample K } & $\begin{array}{c}\text { frakcja/fraction } \\
1-0,8 \mathrm{~mm}\end{array}$ & $\begin{array}{c}\text { frakcja/fraction } \\
0,8-0,5 \mathrm{~mm}\end{array}$ \\
\cline { 2 - 3 } & \multicolumn{2}{c}{$[\%]$} \\
\hline NU & 0,0 & 0,0 \\
RM & 4,9 & 7,0 \\
EL & 1,0 & 0,0 \\
EM/RM & 42,2 & 45,4 \\
EM/EL & 27,4 & 22,7 \\
C & 18,6 & 15,7 \\
Inne/other & 4,9 & 2,6 \\
Kwarc/quartz & 84,0 & 88,0 \\
\hline
\end{tabular}




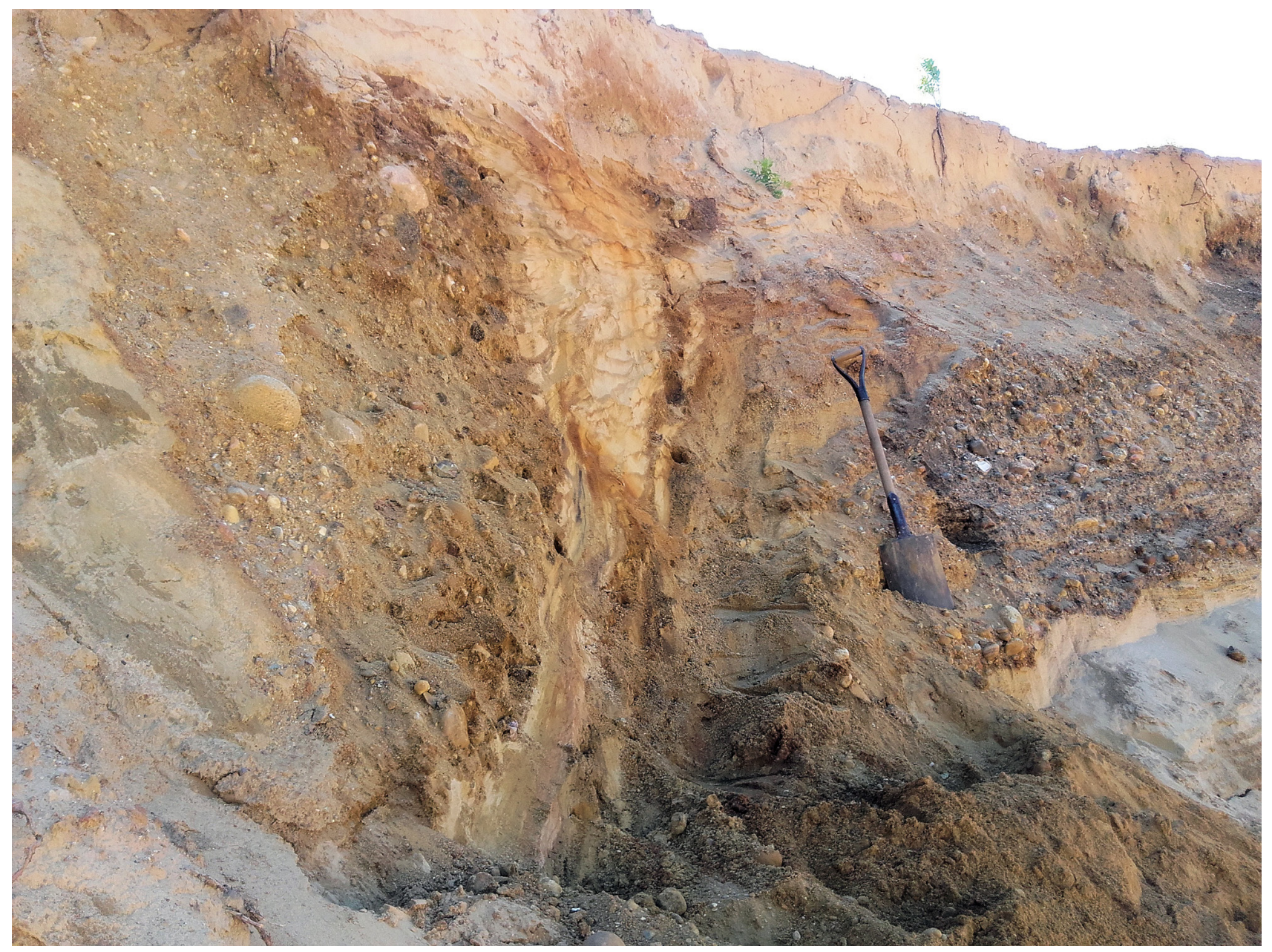

Ryc. 7. Klin mrozowy B

Fig. 7. Frost wedge B

obtoczenie. Charakterystyczną cechą tej próbki jest podwyższona zawartość ziarn pękniętych.

Podobną strukturę dużego klina mrozowego zlokalizowano w zachodniej ścianie piaskowni (ryc. 7, klin B). Struktura ta zaczyna się bezpośrednio pod piaskami pokrywowymi stanowiącymi utwór macierzysty na współczesnej glebie, a zatem jego wiek jest znacznie młodszy. Ugięcie ku dołowi warstw osadu macierzystego świadczy o znacznym udziale lodu $\mathrm{w}$ pierwotnym wypełnieniu szczeliny mrozowej. $Z$ drugiej strony, piaszczysty środek wypełnienia i znajdujący swoją kontynuację w nadległych piaskach pokrywowych pozwala wnioskować, że jest to pseudomorfoza po klinie złożonym.

\section{Dyskusja}

Wykształcenie opisywanych inwolucji (brak regularności oraz różne wymiary zaburzeń) sugeruje, że są to krioturbacje typu 6 według klasyfikacji Vandenberghe (2013). Jednoznaczne przypisanie im genezy mrozowej, czyli działania ciśnienia kriostatycznego lub kriohydrostatycznego (Vandenberghe 1992), na obecnym etapie badań nie jest jednak możliwe. Dżułyński (1963, 1966) oraz Butrym i in. (1964) eksperymentalnie udowodnili, że grunt może ulegać zaburzeniom prowadzącym do rozwoju inwolucji bez udziału procesów mrozowych, gdy spełnione są trzy podstawowe warunki:

1. osad o większej gęstości zalega na osadzie o gęstości mniejszej,

2. warstwy te są przesycone wodą, co zmniejsza lepkość osadów,

3. powstaje impuls naruszający nietrwałą równowagę.

Jednakże warunki takie często występują w strefie peryglacjalnej, w obrębie warstwy czynnej wieloletniej zmarzliny (French 1996), szczególnie w sytuacji wstrząsów glaciizostatycznych (Pisarska-Jamroży $i$ in. 2016). Vanderberghe (1992) uważa, że nie jest konieczna różnica $\mathrm{w}$ gęstości osadów $\mathrm{w}$ profilu pionowym i że inwolucje mogą powstać także w obrębie homogenicznych piasków (Vanderberghe 1988). Należy wziąć pod uwagę fakt, że strop wieloletniej 
zmarzliny mógł się obniżyć, stwarzając dogodne warunki do powstania inwolucji w związku ze zmianą lokalnych warunków środowiskowych, niekoniecznie z powodu zmiany klimatu (French 1987, Murton, French 1993, Shur, Jorgenson 2007). Brak wyraźnego spągu eolicznych piasków pokrywowych oraz falisty charakter bruku pozwala wnioskować, że inwolucje powstały w trakcie pierwszego etapu akumulacji tych piasków.

Wszystkie głaziki w bruku tworzą jeden wyraźny (chociaż nie zwarty) poziom. Bezpośrednio pod brukiem ziarna frakcji kamienistej nie występują. Tak duże ich nagromadzenie i istotny udział głazików ułożonych pod dużym kątem pozwala wnioskować, że działał tu proces podnoszenia mrozowego. Wiek inwolucji z brukiem peryglacjalnym nie jest jeszcze zbadany. Struktury te mogły powstać w schyłku zlodowacenia warty, chociaż wiek vistuliański jest bardziej prawdopodobny, gdyż wówczas obszar badań objęty był po raz ostatni i długotrwale wieloletnią zmarzliną (Goździk 1973, Klatkowa 1996, Mojski 2005, Petera-Zganiacz 2008, Dąbski i in. 2011a).

Niewielką eolizację ziaren kwarcowych wypełniających klin A, przy dobrym obtoczeniu ziaren niekwarcowych, można interpretować jako dyskretny zapis środowiska eolicznego. Wiatr transportował na nieduże odległości piasek, pobierając go z obszarów sandrowych. Duży udział ziaren pękniętych może $z$ kolei być efektem wietrzenia mrozowego, jakiemu poddawany był środek klina (Konishchev 1982, Konishchev, Rogov 1993, French, Guglielmin 2000, Woronko i in. 2015). Klin A musiał powstać $\mathrm{w}$ trakcie powolnej transgresji lądolodu młodszego stadiału warty. Podobne struktury obserwowane były w późnowarciańskich osadach fluwioglacjalnych w regionie lódzkim, $z$ fazy recesyjnej lądolodu (Klatkowa 1996). Natomiast klin B powstał prawdopodobnie w czasie ostatniego zlodowacenia, na co wskazuje powszechność struktur z kontrakcji termicznej występujących blisko współczesnej powierzchni gruntu, tuż pod piaskami pokrywowymi na Niżu Polskim (Różycki 1967, Mojski 1972, 2005, Kozarski 1993, Goździk 1995, Klatkowa 1996, Dzierżek, Stańczuk 2006, Dąbski i in. 2011b, Ewertowski i in. 2016).

\section{Wnioski}

Wstępne wyniki badań na stanowisku ŁubienicaSuperunki dostarczają nowych dowodów wskazujących na funkcjonowanie wieloletniej zmarzliny na północnym Mazowszu w trakcie transgresji lądolodu młodszego stadiału warty (klin mrozowy A) oraz w młodszych okresach plejstocenu (inwolucje, bruk peryglacjalny i klin mrozowy B). Pomimo że inwolucje ani kliny mrozowe nie stanowią dokładnego wskaźnika warunków klimatycznych w plejstocenie (French 1996, Matsuoka 2011), znaczna szerokość i głębokość klinów w piaskowni w Serocku upoważnia do wyciągnięcia wniosków o długotrwałym procesie kontrakcji termicznej w warunkach wieloletniej zmarzliny. Średnica poligonów mrozowych w czasie zlodowacenia warty oraz $\mathrm{w}$ vistulianie musiała być bardzo duża, nawet kilkudziesięciometrowa, gdyż w ścianach piaskowni zaobserwowano tylko po jednym klinie na różnych poziomach stratygraficznych.

\section{Podziękowania i informacje końcowe}

Dziękujemy anonimowym recenzentom za krytyczne i konstruktywne uwagi do pierwszej wersji artykułu.

W dalszej części pracy planujemy wydatować piaszczyste wypełnienia klinów oraz piaski pokrywowe, przeprowadzić bardziej szczegółową analizę struktur peryglacjalnych oraz kontynuować monitoring szybko eksploatowanych ścian piaskowni.

\section{Literatura}

Barczuk A., Mycielska-Dowgiałło E., 2001. Znaczenie składu mineralnego osadów dla rozpoznania obecności procesów eolicznych. W: E. Mycielska-Dowgiałło (red.), Eolizacja osadów jako wskaźnik stratygraficzny czwartorzędu. Wyd. WGSR UW, Warszawa: 39-42.

Beskow G., 1935. Tjälbildningen och tjällyftningen með särskild hänsyn till vägar och järnvägar. Sveriges Geologiska Undersökning ser. C 26(3): 1-375.

Butrym J., Cegła J., Dżułyński S., Nakonieczny S., 1964. New Interpretation of "Periglacial Structures". Folia Quaternaria. 17. Kraków.

Dąbski M., Woronko B., Szwarczewski P., 2011a. Charakterystyka geomorfologiczna stanowiska archeologicznego Feliksów, stanowisko autostradowe nr 79. W: B. Bryńczak, A. Wawrusiewicz (red.), Wyniki archeologicznych badań wykopaliskowych przeprowadzonych w roku 2008-2009 w obrębie stanowiska VIII/1 (AZP 59-61/72, 59-61/73; Aut. 79) w Feliksowie pow. Żyrardów, woj mazowieckie, Siedlce-Białystok 2011. Maszynopis. Archiwum IAE PAN.

Dąbski M., Woronko B., Szwarczewski P., 2011b. Charakterystyka geomorfologiczna stanowiska archeologicznego Dąbrówka, stanowisko autostradowe nr 87. W: Opracowanie wyników ratowniczych badań wykopaliskowych: Dąbrówka, stanowisko II (kod autostradowy 87). Maszynopis. Archiwum IA UW.

Dzierżek J., Stańczuk D., 2006. Record and palaeogegraphical implications of Pleistocene periglacial processes in the Drohiczyn Plateau, Podlasie Lowland (Eastern Poland). Geological Quarterly 50(2): 219-228.

Dżułyński S., 1963. Polygonal structures in Experiments and their Bearing upon some Periglacial Phenomena. Bulletin de L'Academie Polonaise des Sciences, Série des Sciences Géologiques et Géographiques 11(3): 145-150.

Dżułyński S., 1966. O strukturach sedymentacyjnych związanych z niestatecznym uwarstwieniem gęstościowym. Rocznik Polskiego Towarzystwa Geologicznego 36(1): 1-21.

Ewertowski M.W., Kijowski A., Szuman I., Tomczyk A.M., Kasprzak L., 2016, in print. Low-altitude remote sensing and GIS-based analysis of cropmarks: classification of past thermal-contraction-crack polygons in central western Poland. Geomorphology. DOI: 10.1016/j.geomorph.2016.07.022. 
Frankiewicz A., 2017. Materiały robocze do Szczegółowej Mapy Geologicznej Polski w skali 1:50 000, arkusz Serock. PIG, Warszawa.

French H.M., 1987. Permafrost and ground ice. W: K.J. Gregory, D.A. Walling (red.), Human activity and environmental processes. Wiley and Sons Ltd., Chichester: 151-177.

French H.M., 1996. The Periglacial Environment. Longman, Singapore: 1-341.

French H.M., Guglielmin M., 2000. Cryogenic weathering of granite, Northern Victoria Land, Antarctica. Permafrost and Periglacial Processes 11: 305-314.

Goździk J.S., 1973. Geneza i pozycja stratygraficzna struktur peryglacjalnych w środkowej Polsce. Acta Geographica Lodziensia 31: 1-119.

Goździk J.S., 1995. Permafrost evolution and its impact on deposition conditions between 20 and $10 \mathrm{ka}$ BP in Poland. Biuletyn Peryglacjalny 34: 53-72.

Klatkowa H., 1996. Przejawy obecności wieloletniej zmarzliny w środkowej Polsce w ciągu ostatnich 150 tys. lat. Biuletyn Peryglacjalny 35: 73-86.

Konishchev V.N., 1982. Characteristic of cryogenic weathering in the permafrost zone of the European USSR. Arctic and Alpine Research 14: 261-265.

Konishchev V.N., Rogov V.V., 1993. Investigations of cryogenic weathering in Europe and Northern Asia. Permafrost and Periglacial Processes 4: 49-64.

Kozarski S., 1993. Late Plenivistulian deglaciation and the expansion of the periglacial zone in NW Poland. Geologie en Mijnbouw 72: 143-157.

Krumbein W.C., 1941. Measurement and geological record significance of shape and roundness of sedimentary particles. Journal of Sedimentary Research 11: 64-72.

Matsuoka N., 2011. Climate and material controls on periglacial soil processes: Toward improving periglacial climate indicators, Special Issue on Periglacial Processes, Landforms, and Environments in Honor of Link Washburn. Quaternary Research 75(2): 356-365.

Mojski J.E., 1972. Nizina Podlaska. W: R. Galon (red.), Geomorfologia Polski. 2. Niż Polski. PWN, Warszawa: 318-362.

Mojski J.E., 2005. Ziemie polskie w czwartorzędzie. Zarys morfogenezy. PIG, Warszawa: 1-404.
Murton J.B., French H.M., 1993. Thermokrast involutions, Summer Island, Pleistocene Mackenzie Delta, western Canadian Arctic. Permafrost and Periglacial Processes 4: 217-229.

Mycielska-Dowgiałło E., Woronko B., 1998. Analiza obtoczenia i zmatowienia powierzchni ziarn kwarcowych frakcji piaszczystej i jej wartość interpretacyjna. Przegląd Geologiczny 46(12): $1275-1281$.

Petera-Zganiacz J., 2008. Wiek i sposób wykształcenia struktur peryglacjalnych w dolinie dużej rzeki na przykładzie stanowiska Koźmin w dolinie Warty. Landform Analysis 9: 167-170.

Pisarska-Jamroży M., Woronko B., van Loon A.J., 2016. Periglacially-induced versus earthquake-induced load structures - similarities and differences. W: F. Günther, A. Morgenstern (red.), XI. International Conference on Permafrost. Exploring Permafrost in a Future Earth. Book of Abstacts. 20-24 June 2016, Potsdam, Alfred Wegener Institute, Helmholtz Center of Polar and Marine Research, IPA: 335-336.

Różycki S.Z., 1967. Plejstocen Polski środkowej na tle przeszłości w górnym trzeciorzędzie. PWN, Warszawa: 1-251.

Shur Y.L., Jorgenson M.T., 2007. Patterns of the permafrost formation and degradation in relation to climate and ecosystems. Permafrost and Periglacial Processes 18: 7-19.

Vandenberghe J., 1988. Cryoturbations. W: M.J. Clark (red.), Advances in Periglacial Geomorphology. Wiley, Chichester: 179198.

Vandenberghe J., 1992. Cryoturbations: A Sediment Structural Analysis. Permafrost and Periglacial Processes 3: 343-352.

Vandenberghe J., 2013. Cryoturbation Structures. W: S.A. Elias (red.), The Encyclopedia of Quaternary Science. Vol. 3. Elsevier, Amsterdam: 430-435.

van Everdingen R.O., 1998. Multi-Language Glossary of Permafrost and Related Groung-Ice Terms. International Permafrost Association, Calgary.

Woronko B., 2012. Zapis procesów eolicznych w osadach piaszczystych plejstocenu na wybranych obszarach polski środkowej i północno-wschodniej. Wyd. UW WGSR, Warszawa.

Woronko B., Pisarska-Jamroży M., van Loon A.J., 2015. Reconstruction of sediment provenance and transport processes from the surface textures of quartz grains from Late Pleistocene sandurs and an ice-marginal valley in NW Poland. Geologos 21(2): $105-115$. 